\title{
Clarifying a trophic black box: stable isotope analysis reveals unexpected dietary variation in the Peruvian anchovy Engraulis ringens
}

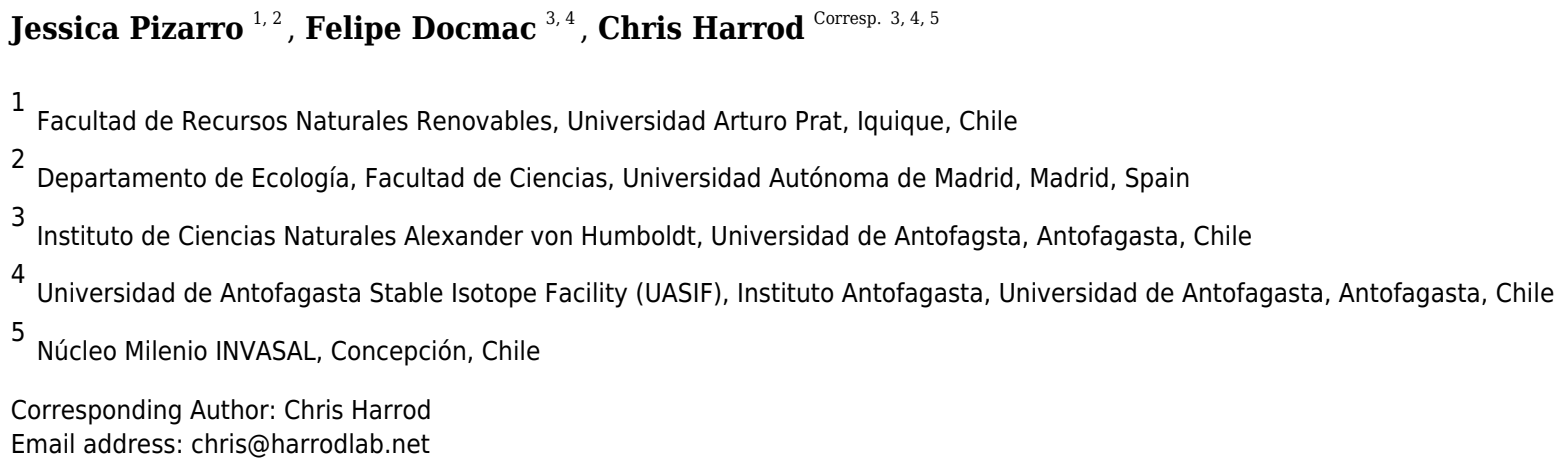

Background Small fishes play fundamental roles in pelagic ecosystems, channelling energy and nutrients from primary producers to higher trophic levels. They support globally important fisheries in eastern boundary current ecosystems like the Humboldt Current System (HCS) of the SE Pacific (Chile and Peru), where fish catches are the highest in the world (per unit area). This production is associated with coastal upwelling where fisheries target small pelagic fishes including the Peruvian anchovy (Engraulis ringens). The elevated biomass attained by small pelagics is thought to reflect their low trophic position in short/simple food chains. Despite their global importance, large gaps exist in our understanding of the basic ecology of these resources. For instance, there is an ongoing debate regarding the relative importance of phytoplankton versus animal prey in anchovy diet, and ecosystem models typically assign them a trophic position (TP) of $\sim 2$, assuming they largely consume phytoplankton. Recent work based on both relative energetic content and stable isotope analysis (SIA) suggests that this value is too low, with $\delta^{15} \mathrm{~N}$ values indicating that anchovy TP is ca. 3.5 in the Peruvian HCS. Methods We characterised the trophic ecology of adult anchovies $(n=30)$, their putative prey and carnivorous jack mackerel $(n=20)$ captured from N Chile. SIA $\left(\delta^{13} C\right.$ and $\left.\delta^{15} N\right)$ was used to estimate the relative contribution of different putative prey resources. $\delta^{15} \mathrm{~N}$ was used to estimate population level trophic position. Results Anchovies showed little variability in $\delta^{13} \mathrm{C}\left(-18.7\right.$ to $-16.1 \%$ ) but varied greatly in $\delta^{15} \mathrm{~N}(13.8$ to $22.8 \%$ ) - individuals formed two groups with low or high $\delta^{15} \mathrm{~N}$ values. When considered as a single group, mixing models indicated that anchovy diet was largely composed of zooplankton (median contribution: 
$95 \%$ credibility limits), with major contributions of crustacean larvae $(0.61: 0.37-0.77)$ and anchovy (preflexion) larvae (0.15: 0.02-0.34), and the assimilation of phytoplankton was negligible (0.05: $0-0.22$ ). The modal (95\% credibility limits) estimate of TP for the pooled anchovy sample was 3.23 (2.93-3.58), overlapping with recent SIA-based estimates from Peru. When the two $\delta^{15} \mathrm{~N}$ groups were analysed separately, our results indicate that the lower $\delta^{15} \mathrm{~N}$ group largely assimilated materials from crustacean larvae $(0.73: 0.42-0.88)$, with a TP of $2.91(2.62-3.23)$. Mixing models suggested high $\delta^{15} \mathrm{~N}$ anchovies were cannibalistic, consuming anchovy preflexion larvae (0.55: $0.11-0.74)$. A carnivorous trophic niche was supported by high TP (3.79: 3.48-4.16), mirroring that of carnivorous juvenile jack mackerel (Trachurus murphyi; 3.80: 3.51-4.14). Our results support recent conclusions regarding high TP values of anchovy from Peru and reveal new insights into their trophic behaviour. These results also highlight the existence of cryptic trophic complexity and ecosystem function in pelagic food webs, classically considered as simple. 


\section{Clarifying a trophic black box: stable isotope analysis}

3 reveals unexpected dietary variation in the Peruvian 4 anchovy Engraulis ringens.

\section{Abstract \\ Background}

Small fishes play fundamental roles in pelagic ecosystems, channelling energy and nutrients from primary producers to higher trophic levels. They support globally important fisheries in eastern boundary current ecosystems like the Humboldt Current System (HCS) of the SE Pacific (Chile and Peru), where fish catches are the highest in the world (per unit area). This production is associated with coastal upwelling where fisheries target small pelagic fishes including the Peruvian anchovy (Engraulis ringens). The elevated biomass attained by small pelagics is commonly thought to reflect their low trophic position in short/simple food chains. Despite their 
33 global importance, large gaps exist in our understanding of the basic ecology of these resources.

34 For instance, there is an ongoing debate regarding the relative importance of phytoplankton

35 versus animal prey in anchovy diet, and ecosystem models typically assign them a trophic

36 position (TP) of $\sim 2$, assuming they largely consume phytoplankton. Recent work based on both

37 relative energetic content and stable isotope analysis (SIA) suggests that this value is too low,

38 with $\delta^{15} \mathrm{~N}$ values indicating that anchovy TP is ca. 3.5 in the Peruvian HCS.

39

\section{Methods}

41 We characterised the trophic ecology of adult anchovies $(n=30)$, their putative prey and

42 carnivorous jack mackerel $(n=20)$ captured from $N$ Chile. SIA $\left(\delta^{13} \mathrm{C}\right.$ and $\left.\delta^{15} \mathrm{~N}\right)$ was used to

43 estimate the relative contribution of different putative prey resources. $\delta^{15} \mathrm{~N}$ was used to estimate

44 population level trophic position.

\section{Results}

47 Anchovies showed little variability in $\delta^{13} \mathrm{C}\left(-18.7\right.$ to $-16.1 \%$ ) but varied greatly in $\delta^{15} \mathrm{~N}$ (13.8 to $4822.8 \%$ ), and individuals formed two groups with low or high $\delta^{15} \mathrm{~N}$ values. When considered as a 49 single group, mixing models indicated that anchovy diet was largely composed of zooplankton 50 (median contribution: 95\% credibility limits), with major contributions of crustacean larvae 51 (0.61: 0.37-0.77) and anchovy (preflexion) larvae (0.15: 0.02-0.34), and the assimilation of 52 phytoplankton was negligible (0.05: 0-0.22). The modal (95\% credibility limits) estimate of TP 53 for the pooled anchovy sample was 3.23 (2.93-3.58), overlapping with recent SIA-based 54 estimates from Peru. 
56 When the two $\delta^{15} \mathrm{~N}$ groups were analysed separately, our results indicate that the lower $\delta^{15} \mathrm{~N}$

57 group largely assimilated materials from crustacean larvae (0.73: 0.42-0.88), with a modal

58 estimated TP of $2.91(2.62-3.23)$. Mixing models suggested high $\delta^{15} \mathrm{~N}$ anchovies were

59 cannibalistic, consuming anchovy preflexion larvae (0.55: 0.11-0.74). A carnivorous trophic

60 niche was supported by high TP (3.79: 3.48-4.16), mirroring that of carnivorous juvenile jack

61 mackerel (Trachurus murphyi; 3.80: 3.51-4.14).

62

63 Our results support recent conclusions regarding high TP values of anchovy from Peru, and 64 reveal new insights into their trophic behaviour. These results also highlight the existence of 65 cryptic trophic complexity and ecosystem function in pelagic food webs, which are classically 66 considered as simple.

67

68 Introduction

69 Boundary current ecosystems such as the Humboldt Current System (HCS) are characterised by 70 high biological productivity driven by coastal upwelling of cold sub-surface nutrient-rich waters 71 (Chavez \& Messié 2009). Food chains in such ecosystems have been typically considered as 72 simple and short (Ryther 1969), with high efficiency of trophic transfer between trophic levels.

73 Here, phytoplankton form the base of the food web, and are consumed by zooplankton and small74 bodied pelagic fishes such as the Peruvian anchovy Engraulis ringens Jenyns, 1842 (from hereon 75 in, anchovy). The small pelagic fish assemblage is typically dominated by one or a few species 76 (Bakun 1996), which due to their sheer abundance and biomass can exercise control over the 77 trophic dynamics of the whole ecosystem (Cury 2000). 
79 Biological production in the HCS (Herrera \& Escribano 2006) is such that it supports the capture of

80 more fish per unit area than any other environment in the world (Chavez et al. 2008). Indeed,

81 production in the HCS is considered anomalous, even among eastern current systems (Bakun \&

82 Weeks 2008; Chavez \& Messié 2009). Industrial fisheries in Peru and Chile target anchovies and 83 other pelagic fishes such as jack mackerel Trachurus murphyi and sardines (Sardinops sagax). The

84 anchovy stock in the region is the most heavily exploited fish worldwide: although annual catches 85 vary considerably reflecting the marked effects of ENSO on stock size, between 1990 and 2015, on 86 average (median \pm IQR) $7419295 \pm 3329637$ tonnes of anchovies were removed per year (FAO 87 2018).

88

89 Although anchovy (and other small pelagics) support globally important fisheries (Chavez \& 90 Messié 2009; Kämpf \& Chapman 2016), and play integral roles in structuring upwelling 91 ecosystems (Cury 2000), many basic aspects of their ecology are understudied. For instance, 92 information on their trophic ecology is limited, and likely constrains our understanding of their 93 role in the HCS, and the utility of ecosystem model outputs. Studies of anchovy diet based on 94 stomach content analysis (SCA) of juveniles and adults typically report that stomach contents are 95 dominated (in numerical terms) by phytoplankton (Espinoza \& Bertrand 2008; Medina et al. 96 2015; Ryther 1969), and anchovies have been classically considered as phytoplanktivores. This 97 low trophic position has been proposed as an explanation for their great abundance in the HCS, 98 and the ecosystem's anomalous capacity to support such high production of pelagic fishes.

100 Most studies of anchovy diet in the literature are based on counts of individual stomach contents, 101 which is known to bias conclusions when prey of markedly different sizes are consumed (Hyslop 
102 1980). Not surprisingly, microscopic food items such as diatoms can be extremely abundant,

103 leading them to dominate relative estimates of prey importance (up to $98 \%$ : Whitehead et al.

104 1998), even though zooplankton are commonly reported from anchovy stomach contents. Given

105 the putative importance of phytoplankton to their diet, many researchers have assumed that

106 anchovy have a trophic position of ca. 2 - 2.5 (Guénette et al. 2008; Pauly et al. 1998). These

107 values are commonly used in ecosystem models such as Ecopath, and anchovies are considered a

108 classic low-trophic level species (Smith et al. 2011). This estimate of anchovy TP has played an

109 important role in one of the largest controversies in modern fisheries science - the issue of global

110 fishing down the food web (Pauly et al. 1998; Pauly et al. 2000). The global importance of the

111 HCS anchovy fishery is such that if its statistics are included, it skews global estimates of the

112 mean trophic level of catch downward.

113

114 More recently however, there has been an important reassessment of anchovy diet. Espinoza \&

115 Bertrand (2008), rather than counting stomach contents, focused on the energetic content of prey,

116 and clearly showed that zooplankton (mainly copepods and euphausiids) were the principle

117 source of energy to anchovies. Beyond highlighting a key issue of using counts of stomach

118 contents to estimate TP, their results had major implications regarding our understanding of how

119 this globally important marine ecosystem functions (e.g. e.g. Ballón et al. 2011). Given the

120 biomass of anchovies in the HCS, and their dominant role in the food web, changes in our

121 understanding of their putative diet has subsequent impacts on how we interpret the movement of

122 energy and nutrients through the food web, with consequences for qualitative and quantitative

123 models of HCS function and resource management. 
125 SCA has long been the gold standard for assessing what fish consume (Hynes 1950; Hyslop

126 1980), but clearly can bias our understanding of how fish direct the flow of materials through a

127 food web (Espinoza \& Bertrand 2008; Hyslop 1980). An alternative to the snapshot of recently

128 ingested prey provided by SCA, is to take a biochemical approach to assessing diet such as stable

129 isotope analysis (SIA) or fatty acid analysis (Nielsen et al. 2018). The advantages of SIA in

130 particular, are that the technique provides information on prey assimilation over longer temporal

131 scales than SCA (weeks - months), with the period depending on the tissue sampled (Thomas \&

132 Crowther 2015). By combining analysis of carbon and nitrogen stable isotope ratios of

133 consumers and their putative prey, it is possible to characterise the source of energy and nutrients

134 assimilated by a consumer (Parnell et al. 2013). Furthermore, if isotope values are available for

135 both the consumer and the base of the food web (Vander Zanden \& Rasmussen 1996), it is

136 possible to estimate the long term trophic position at which a consumer feeds (Quezada-

137 Romegialli et al. 2018).

138

139 Recent work in Central Chile and Peru using SIA has provided further evidence that previous

140 assumptions regarding anchovy trophic position were wrong. Hückstadt et al. (2007) compared

141 POM and anchovy $\delta^{15} \mathrm{~N}$ values from central Chile and estimated anchovy TP as 3.6. In a wide-

142 ranging recent study from the northern HCS, Espinoza et al. (2017) compared anchovy (and

143 other taxa) $\delta^{15} \mathrm{~N}$ values relative to copepod $\delta^{15} \mathrm{~N}$ to estimate TP. They estimated that anchovy TP

144 ranged between 3.4 and 3.7. Both of these studies provide evidence that anchovy TP is at least a

145 trophic level above values typically used for the species in trophic models (Guénette et al. 2008;

146 Pauly et al. 1998), and challenge the concept of anchovies as a low trophic level fish (Smith et al.

147 2011). Espinoza et al.'s (2017) estimates for anchovy TP are important as they support the

148 authors previous findings from SCA indicating that phytoplankton, although abundant 
149 numerically in stomachs, did not make a major contribution to assimilated diet. However, their 150 and Hückstadt et al.'s (2007) estimates were based on a simple model which does not include 151 isotopic variation in trophic discrimination or in the baseline itself (see Quezada-Romegialli et 152 al. 2018 for a description of the issue). The latter point is particularly important in the Espinoza 153 et al. (2017) case, as the use of copepods as a baseline likely introduces considerable error 154 compared to e.g. the use of a primary producer, given the range of trophic strategies displayed by 155 pelagic marine copepods (Giesecke \& González 2004) and the uncertainties in allocating a TP 156 for mixed samples of copepods.

157

158 It is becoming increasingly apparent that food webs associated with upwelling ecosystems can be 159 more complex and dynamic than previously thought (Docmac et al. 2017; Espinoza \& Bertrand 160 2008). As such, there is a need for improved understanding of how these systems function, in 161 order to inform and update existing trophic models used to explain the flow of energy and 162 nutrients, as well as to allow an informed management of a globally important fishery. Here, we examine the trophic ecology of adult anchovies from northern Chile using stable isotope ratios of

164 165 anchovies and their putative prey to estimate the relative role of phytoplankton and other prey, and to provide robust estimates of anchovy trophic position. Given the debate over the trophic ecology of anchovy, we compared their stable isotope values with that of juvenile jack mackerel, a known pelagic carnivore (Alegre et al. 2015; Orrego \& Mendo 2015).

\section{Materials \& Methods}




\section{Study area}

172 Samples were collected between $20^{\circ} 30^{\prime} \mathrm{S}$ and $21^{\circ} 30^{\prime} \mathrm{S}$ off the coast of northern Chile (Fig. 1)

173 during the Austral winter of 2008. This area is characterized for having persistent winds that permit

174 year-round upwelling (although upwelling often strengthens during Spring-Summer), generating

175 the intrusion of cold nutrient rich sub-surface waters along the shore (Thiel et al. 2007).

176 During the study period, neutral environmental conditions were present (i.e. non-ENSO). Sea

177 surface temperatures ranged between 15.2 and $17.5{ }^{\circ} \mathrm{C}$, salinities varied between 34.6 and 34.9

178 and surface dissolved oxygen concentrations between 4.2 and $6.7 \mathrm{ml}^{-1} \mathrm{I}^{-1}$ In general terms, the study

179 area was characterized by a low-magnitude permanent upwelling, more marked around a latitude 180 of $21^{\circ} 10^{\prime}$ S (Fuenzalida et al. 2009).

181

\section{Sample collection}

183 Fish were captured (Fig. 1) at $20^{\circ} 57^{\prime} \mathrm{S}-70^{\circ} 22^{\prime} \mathrm{W}$ (adult anchovies) and $20^{\circ} 59^{\prime} \mathrm{S}-70^{\circ} 23^{\prime} \mathrm{W}$ (juvenile

184 jack mackerel to allow comparisons with a known carnivorous fish) by the fishing vessel Atacama $185 \mathrm{~V}$, using a commercial purse seine (mesh $15 \mathrm{~mm}$ ). Once captured, fish were frozen at $-20^{\circ} \mathrm{C}$ until 186 further analysis. Permission to undertake field sampling was provided by the Chilean Subsecretaría 187 de Pesca through Resolución Exenta Nº 2205 (21 August 2008).

189 Samples of putative planktonic prey (phytoplankton and zooplankton) were collected during 190 daylight hours following a grid design along four longitudinal transects (latitudinal distance 191 between transects 15 nautical miles), located perpendicular to the N Chilean coast (Fig. 1). Each 192 longitudinal transect included 4 stations, located at 1, 3, 5 and 10 nautical miles from the coast, 193 resulting in a total of 16 sampling sites. Phytoplankton was collected via vertical tows (from 50 
$194 \mathrm{~m})$ of a phytoplankton net (20 $\mu \mathrm{m}$ mesh size, $20 \mathrm{~cm}$ opening). Zooplankton was collected through 195 vertical tows (max. depth $100 \mathrm{~m}$, but varied with sampling station depth) of a WP-2 net (300 $\mu \mathrm{m}$ 196 mesh size, of $50 \mathrm{~cm}$ opening). Samples were immediately frozen at $-20^{\circ} \mathrm{C}$, and following transfer 197 to the laboratory placed in a $-80^{\circ} \mathrm{C}$ freezer.

198

199 Laboratory analysis

200 Once defrosted, total length (TL: $\pm 1 \mathrm{~mm})$ and blotted wet mass $( \pm 0.1 \mathrm{~g})$ were estimated for anchovy $201(\mathrm{n}=30)$ and jack mackerel $(\mathrm{n}=20)$. Stomachs were removed for analysis of stomach contents, but 202 on inspection, a large majority of anchovy stomach contents were found to be in an advanced stage 203 of digestion, limiting the utility of SCA in this case and we do not consider these data further in this 204 study.

205 A sample of dorsal muscle was excised and treated with chloroform:methanol (2:1) to extract lipids 206 (Bligh \& Dyer 1959). Samples were then oven dried $\left(60^{\circ} \mathrm{C}\right.$ for 48 hours) and homogenised prior to 207 analysis of carbon and nitrogen stable isotope values.

208

209 Prior to SIA, phytoplankton samples were pre-filtered through a $200 \mu \mathrm{m}$ sieve to remove 210 zooplankton and large detritus. Zooplankton were sorted into different components: anchovy eggs 211 and larvae, unidentified fish eggs, amphipods, appendicularians, chaetognaths, copepods, 212 crustacean larvae, euphausiids, ostracods, pelagic polychaetes, salpidae and siphonophora. Each 213 of these groups were pooled to obtain sufficient mass for SIA.

214

215 Phytoplankton and zooplankton samples were washed with milli-Q water and then filtered through 216 pre-combusted $\left(450^{\circ} \mathrm{C} \times 4 \mathrm{~h}\right) \mathrm{GF} / \mathrm{F}$ filters (Whatmann, $0.7 \mu \mathrm{m}$ pore size, $47 \mathrm{~mm}$ diameter). Filters 
217 were subsequently oven dried $\left(60^{\circ} \mathrm{C}\right.$ for 48 hours), then acidified by directly applying $\mathrm{HCl}(1 \mathrm{~N})$ for

$21824 \mathrm{~h}$ to remove inorganic carbon and re-dried (Carabel et al. 2006). Zooplankton samples were then

219 scraped off filters prior to homogenisation. Fish and zooplankton samples were homogenised with an

220 agate mortar and pestle and weighed into tin capsules (sample mass $\sim 0.5 \mathrm{mg}$ ). Phytoplankton samples

221 were run from sections of GF/F filters.

222

223

Analysis of $\delta^{13} \mathrm{C}$ and $\delta^{15} \mathrm{~N}$ were conducted at the Colorado Plateau Stable Isotope Laboratory in 224

Northern Arizona University (USA) using a Costech ECS4010 elemental analyser coupled to a 225

Delta Plus Advantage isotope ratio mass spectrometer in continuous flow mode via a ConFlo III 226 interface. Isotopic abundances are expressed in $\delta$ notation (\%o), using the formula $\delta^{13} \mathrm{C}$ or $\delta^{15} \mathrm{~N}=$ 227 $\left[\left(\mathrm{R}_{\text {sample }}-\mathrm{R}_{\text {standard }}\right) / \mathrm{R}_{\text {standard }}\right] \times 10^{3}$; where: $\mathrm{R}_{\text {sample }}$ is ${ }^{13} \mathrm{C} /{ }^{12} \mathrm{C}$ or ${ }^{15} \mathrm{~N} /{ }^{14} \mathrm{~N}, \mathrm{R}_{\text {standard }}$ is Vienna Pee Dee Belemnite for $\delta^{13} \mathrm{C}$ and atmospheric nitrogen for $\delta^{15}$ N. NIST 1547 (peach leaves) were used as an 229 internal laboratory working standard to check on measurement reproducibility throughout each run (analytical precision of $\leq 0.1 \%$ for $\delta^{13} \mathrm{C}$ and $\leq 0.2 \%$ for $\delta^{15} \mathrm{~N}$ ). A number of peach leaf 231 standards that varied in mass (from 0.5 to $6 \mathrm{mg}$ ) were also included at the end of the run to check on linearity. Analytical data were normalized to international standards using calibrated reference standards with known $\delta^{13} \mathrm{C}$ (IAEA CH6 \& IAEA CH7) or $\delta^{15} \mathrm{~N}$ (IAEA N1 \& IAEA N2) values.

\section{Data analysis}

Data were plotted in the form of an $\delta^{15} \mathrm{~N}-\delta^{13} \mathrm{C}$ scatterplot to provide a visual representation of the distribution of isotopic values for the different taxa examined, and to examine putative differences between anchovy and jack mackerel. Individual data were plotted for fish, while putative prey were plotted as means \pm SD. Size differences between the fish species were examined using the

240 Welch's t-test. We examined potential relationships between fish isotope values and their 
241 individual body mass using Spearman's rank correlation coefficient. Both Welch's t-tests and

242 correlations were conducted in SYSTAT 13.1 (SYSTAT Software Inc 2009). Unless otherwise

243 reported, summary statistics reflect mean $\pm 1 \mathrm{SD}$.

244

245 In order to examine whether the two fish species differed isotopically, we compared $\delta^{15} \mathrm{~N}-\delta^{13} \mathrm{C}$

246 centroids of anchovies and jack mackerel using a permutation-based multivariate analysis of 247 variance (PERMANOVA: $\mathrm{n}_{\text {permutations }}=9,999$ ), based on a Euclidean similarity matrix of 248 untransformed $\delta^{15} \mathrm{~N}-\delta^{13} \mathrm{C}$ data (Anderson et al. 2008). Due to an apparent sub-structuring within 249 the anchovies based on $\delta^{15} \mathrm{~N}$ values (see below), we also tested for differences between the two 250 observed groups of anchovies using a similar approach. PERMANOVA analyses were conducted 251 in PRIMER with PERMANOVA 7.0.13 (Anderson et al. 2008; Clarke \& Gorley 2015).

252

253 We used the R-based (version 3.5.0; R Core Team 2018) Bayesian mixing model SIMMR to 254 estimate the relative contribution of seven different key putative prey groups to anchovy and jack 255 mackerel assimilated diet, (https://cran.r-project.org/web/packages/simmr/index.html). These 256 groups were selected reflecting their abundance in zooplankton hauls and literature descriptions of 257 anchovy diet (Espinoza \& Bertrand 2008; Medina et al. 2015). SIMMR was run in RStudio 258 (version 1.1.447; RStudio Team 2016) using default settings for the number of iterations, burn in 259 and Markov chain Monte Carlo (MCMC) chains. Putative prey were grouped a priori as anchovy 260 eggs, anchovy larvae, copepods, crustacean larvae, euphausiids, unidentified fish eggs and 261 phytoplankton. We used mean $\pm \mathrm{SD}$ trophic discrimination factors from Post $(2002)\left(\Delta^{13} \mathrm{C}=0.4\right.$ $262 \pm 1.3 \% ; \Delta^{15} \mathrm{~N}=3.4 \pm 1.0 \%$ ) , and included information on prey elemental concentrations. 
263 We estimated TP of anchovy and jack mackerel in R using the Bayesian package

264 tRophicPosition (Quezada-Romegialli et al. 2018), using the Onebaseline model. Briefly, the

265 tRophicPosition model includes isotopic variation in the baseline indictor, the consumer and in

266 the trophic discrimination in order to provide a robust estimation of consumer TP at the

267 population level. We included the phytoplankton $\delta^{15} \mathrm{~N}$ data to provide the baseline $(\lambda=1)$, and

268 assumed a trophic discrimination factor $\left(\Delta^{15} \mathrm{~N}\right)$ of $3.4 \pm 1 \%$ (Post 2002).

269

270 Results

271 Isotopic values for the different taxa analysed are shown in Fig. 2. Phytoplankton had a mean $\delta^{13} \mathrm{C}$

272 value of $-18.6 \%$ but showed considerable variation between sampling locations $(\mathrm{SD}=1.6 \%$ ).

273 Phytoplankton mean $\delta^{15} \mathrm{~N}$ was $12.4( \pm 1.3)$, reflecting the influence of ${ }^{15} \mathrm{~N}$-enriched upwelling-

274 derived $\mathrm{NO}_{3}$, and apparently formed the basal resource for consumers from overlying trophic

275 levels. Carbon stable isotope values for the different putative zooplankton prey classes (anchovy

276 eggs and larvae, unidentified fish eggs, copepods, crustacean larvae, euphausiids) ranged between $277-20.3 \%$ and $-17.9 \%$ for $\delta^{13} \mathrm{C}$ and $15.1 \%$ to $19.7 \%$ for $\delta^{15} \mathrm{~N}$.

278 Carbon and nitrogen stable isotope values were estimated from 30 adult anchovies (28 male, 2 279 female). Anchovy TL varied between 13.7 and $16.1 \mathrm{~cm} \mathrm{TL}$ (mean TL $=14.8 \pm 0.6 \mathrm{~cm}$ ), and blotted 280 wet mass between $13.9 \mathrm{~g}$ and $25.7 \mathrm{~g}(19.5 \pm 2.9 \mathrm{~g})$. Juvenile jack mackerels ( 1 male, 1 female, 18 281 indeterminate) TL varied between 18.5 and $22.2 \mathrm{~cm}(19.5 \pm 1.1 \mathrm{~cm})$, and mass between 43.2 and $282 \quad 79.8 \mathrm{~g}(53.7 \pm 9.8 \mathrm{~g})$.

283

284 Anchovy lipid-free $\delta^{13} \mathrm{C}$ values varied between -18.7 and $-16.1 \%$, with a mean of $-17.1 \pm 0.6 \%$. 285 Variation in $\delta^{15} \mathrm{~N}$ values was more marked, with individual anchovies ranging between 13.8 and $28622.8 \%$, and a mean $\delta^{15} \mathrm{~N}$ of $19.7( \pm 1.9) \%$. Examination of anchovy $\delta^{15} \mathrm{~N}$ values revealed the 
287 presence of two apparent groups differing in their $\delta^{15} \mathrm{~N}$ values: one group was relatively ${ }^{15} \mathrm{~N}$ 288 enriched $(21.6 \pm 0.9 \%)$, and the second was made up of ${ }^{15} \mathrm{~N}$-depleted individuals $(18.5 \pm 1.3 \%)$.

289

290 Jack mackerel lipid-free $\delta^{13} \mathrm{C}$ values ranged between -18.4 and $-17.6 \%$ (mean $\delta^{13} \mathrm{C}-18.0 \pm 0.2$

$291 \%$, while their $\delta^{15} \mathrm{~N}$ values ranged between 18.3 and $22.2 \%$, with a mean $\delta^{15} \mathrm{~N}$ of $21.6( \pm 0.9)$

$292 \%$, apparently similar to that of the high $\delta^{15} \mathrm{~N}$ group of anchovies.

293

294 There was no evidence of correlation between the isotopic composition and mass (Fig. 3) of 295 anchovy $\left(\delta^{13} \mathrm{C}: \mathrm{r}_{\mathrm{S}}=-0.02, \mathrm{P}=0.94 ; \delta^{15} \mathrm{~N}: \mathrm{r}_{\mathrm{s}}=0.11, \mathrm{P}=0.56\right)$. Jack mackerel $\delta^{13} \mathrm{C}$ was similar 296 across the size range examined $\left(r_{\mathrm{s}}=-0.27, \mathrm{P}=0.27\right)$ but showed a positive relationship between 297 mass and $\delta^{15} \mathrm{~N}\left(\delta^{15} \mathrm{~N}: \mathrm{r}_{\mathrm{s}}=0.55, \mathrm{P}=0.01\right)$. Anchovies were significantly smaller than jack mackerel 298 (Welch's $t$ test of mass: $t_{28.1}=-15.1, \mathrm{P}<0.001$ ), but there was no evidence for any size difference 299 between the two anchovy groups $\left(\mathrm{t}_{17.2}=0.70, \mathrm{P}=0.493\right)$.

300

301

302 PERMANOVA indicated that $\delta^{13} \mathrm{C}-\delta^{15} \mathrm{~N}$ centroids differed between the anchovy and jack 303 mackerel (Pseudo- $\left.F_{1,49}=20.6, P=0.0001\right)$. When anchovies are considered as two different groups 304 (high and low $\delta^{15} \mathrm{~N}$ ), there was again strong evidence for isotopic differences between the three 305 groups of fish compared: low $\delta^{15} \mathrm{~N}$ adult anchovies, high $\delta^{15} \mathrm{~N}$ adult anchovies and juvenile jack 306 mackerel (Pseudo- $\left.F_{2,49}=45.2, P=0.0001\right)$. Pairwise tests however revealed significant overlap 307 between juvenile jack mackerel and the individuals in the high $\delta^{15} \mathrm{~N}$ anchovy group $(\mathrm{P}=0.11)$. 308 Anchovies from the low $\delta^{15} \mathrm{~N}$ group were isotopically different from both $(\mathrm{P}=0.0001$ in both 309 cases). 
311 A univariate PERMANOVA showed significant differences in $\delta^{13} \mathrm{C}$ between groups (Pseudo- $\mathrm{F}_{2,49}$ $312=30.3, \mathrm{P}=0.0001$ ), with higher $\delta^{15} \mathrm{~N}$ anchovies being ca. $0.6 \%$ depleted in ${ }^{13} \mathrm{C}$ compared to 313 individuals from the lower $\delta^{15} \mathrm{~N}$ group. A similar analysis showed that the three groups of fish 314 differed in their $\delta^{15} \mathrm{~N}$ values $\left(\right.$ Pseudo- $\left._{2,49}=47.9, \mathrm{P}=0.0001\right)$ and that the group of anchovies

315 lower in $\delta^{15} \mathrm{~N}$ was ${ }^{15} \mathrm{~N}$ depleted by ca. $3 \%$ (close to one trophic level given a TDF of $3.4 \%$ ) 316 compared to the higher $\delta^{15} \mathrm{~N}$ anchovies and the jack mackerel (Pairwise $\mathrm{P}=0.0001$ ). $\delta^{15} \mathrm{~N}$ values 317 overlapped between the high $\delta^{15} \mathrm{~N}$ anchovy group and the jack mackerel $(\mathrm{P}=0.74)$, suggesting a 318 similar feeding mode.

319

320

Mixing models

321 Mixing models results (Fig. 4, Table 1) indicate that all fish examined were carnivorous, with little 322 evidence for large-scale contributions by phytoplankton. When considered as a single group, 323 anchovies largely assimilated carbon and nitrogen from crustacean larvae (median estimate $=61$ 324 $\%)$ and anchovy larvae (15\%), with phytoplankton making a minor contribution (5\%). When 325 considered separately, the anchovy group with high $\delta^{15} \mathrm{~N}$ values had a large contribution of 326 anchovy larvae in their diet (55\%), while the low $\delta^{15} \mathrm{~N}$ anchovy group were estimated to have assimilated the majority of their carbon and nitrogen from crustacean larvae (73\%). Mixing model results indicated that anchovy larvae (39\%), unidentified fish eggs (19\%) and anchovy eggs (15 329 \%) all made major contributions to the assimilated diet of jack mackerel. Comparison between the mixing model results for the high $\delta^{15} \mathrm{~N}$ group of anchovies and jack mackerel indicated that they had broadly similar foraging modes. 
334 Bayesian estimates of TP supported the mixing model results, with credibility limits for all fish 335 including TP 3 (Fig. 5). Modal (95\% credibility limits) estimated TP for the pooled anchovy 336 sample was $3.23(2.93-3.58)$. The low $\delta^{15} \mathrm{~N}$ anchovy group had a lower estimated TP (2.91:

$3372.62-3.23)$. Estimates of TP for the high $\delta^{15} \mathrm{~N}$ anchovy group (3.79: $\left.3.48-4.16\right)$ and jack 338 mackerel (3.80: $3.51-4.14)$ were highly similar.

339

340

341

342

343

344 345

346 347 348 349 350 351 352 353 354 355 356 357

\section{Discussion}

Our study aimed to further our understanding of the trophic ecology of the Peruvian anchovy - a fish that supports the most productive fishery in the world. Existing data on anchovy diet, like that of other pelagic fishes, is largely derived from the analysis of stomach contents, and has generally concluded that anchovy production in the study region is fuelled by the consumption of phytoplankton (Castillo et al. 2002; Medina et al. 2015) and to a lesser degree, copepods (Castillo et al. 2011). Our results, based on stable isotope values, indicate that the contribution of phytoplankton to anchovy somatic tissues is minimal and that zooplankton represents the main food source assimilated by anchovies. Our results follow those of Espinoza and colleagues (Espinoza \& Bertrand 2008; Espinoza et al. 2017), who have elegantly demonstrated that a reliance on stomach content data has resulted in a significant misinterpretation of anchovy trophic ecology and by extension, the food web of the HCS. Beyond our reaffirmation of Espinoza et al's observations (2017) regarding the trophic position of anchovy, we have also identified several previously unknown features of the pelagic food web of the Chilean HCS, suggesting that the trophic ecology of the Peruvian anchovy, and ecosystem function in the HCS are both more complex than is typically considered. 
358 The HCS has several characteristic features associated with elevated fisheries production. Using

359 stable isotopes of anchovies, jack mackerel and their putative prey, as well as the key pelagic

360 primary producer, phytoplankton, we were able to highlight the influence of upwelling throughout

361 the food chain in the Chilean HCS. Phytoplankton and higher trophic levels were naturally-labelled

362 with heavy nitrogen associated with upwelling (Casciotti 2016; Docmac et al. 2017; Reddin et al.

363 2015), and results indicate that phytoplankton was the likely carbon source fuelling upper trophic

364 levels in the HCS. We used phytoplankton collected across the survey area both as a putative food

365 source in mixing models and as a baseline for the estimation of trophic position. Phytoplankton

$366 \delta^{13} \mathrm{C}$ values varied by ca. $3 \%$ between locations, likely reflecting local differences in primary

367 production rates due to variation in upwelling intensity, $\mathrm{CO}_{2}$ concentrations, phytoplankton growth

368 rate etc., (Magozzi et al. 2017) and possibly community composition (Fry \& Wainright 1991). It

369 is notable that several taxa examined here were notably ${ }^{15} \mathrm{~N}$-enriched relative to their counterparts

370 in the northern HCS reported by Espinoza et al. (2017) (e.g. copepods by $7.5 \%$, euphausiids by

$3717.6 \%$, anchovies by $7.6 \%$ and jack mackerel by $4.1 \%$ ). This likely reflects regional differences

372 in upwelling intensity.

373

374 Anchovies have typically been considered to have homogeneous diets and therefore trophic

375 position (Medina et al. 2015). Using SIA, however, we have shown the existence of considerable

376 inter-individual differences in $\delta^{15} \mathrm{~N}$, a robust indicator of trophic position (Post 2002). The

377 differences between the two approaches presumably reflects an overestimation on the contribution

378 of phytoplankton due to using count data (Espinoza \& Bertrand 2008) as well as the different

379 timescales associated with SCA (hours) compared with SIA (months) (Nielsen et al. 2018; Thomas 
380 \& Crowther 2015), but highlights the power of SIA to identify cryptic individual variation (Bolnick 381 et al. 2002; Harrod et al. 2005).

382

383 The observed variability in $\delta^{15} \mathrm{~N}$ values for adult anchovies very likely reflects differences in 384 individual feeding strategies. We identified two trophic groups, one relatively enriched in ${ }^{15} \mathrm{~N}$, 385 associated with the consumption of anchovy larvae, and another, depleted in ${ }^{15} \mathrm{~N}$ that largely 386 consumed crustacean larvae. Anchovies from the first group had similar $\delta^{15} \mathrm{~N}$ values to juvenile 387 jack mackerel, implying that they fed at a similar TP: however they differed in $\delta^{13} \mathrm{C}$ values, likely 388 indicating resource segregation. Anchovies in the lower $\delta^{15} \mathrm{~N}$ group had a modal ( $95 \%$ credibility 389 interval) estimated TP of $2.91(2.62-3.23)$ indicating some omnivory, but a largely carnivorous diet. Anchovies in the higher $\delta^{15} \mathrm{~N}$ group had a modal value of $3.79(3.48-4.16)$ which overlapped 391 completely with carnivorous jack mackerel (3.80 (3.51 - 4.14)), indicating that they are

392 functionally similar. Support for a high TP for some anchovy is provided by Espinoza et al. (2007) 393 who also showed overlap between jack mackerel $\delta^{15} \mathrm{~N}$ values and anchovies with high $\delta^{15} \mathrm{~N}$ values 394 from southern Peruvian latitudes.

395

396

397 398 399 400 401
When the two anchovy groups were pooled, estimated TP $(3.23(2.93-3.58))$ was ca. 1 TP higher than values estimated from stomach contents data and widely used in modelling studies (Guénette et al. 2008; Pauly et al. 1998). However, these pooled estimates effectively overlap with values from other studies using stable isotope analysis, such as Hückstadt et al. (2007) working in central Chile (anchovy TP = 3.6) and Espinoza et al. (2017) from the Peruvian part of the HCS (3-4 - 3.7). 
402 Our sample of anchovy was relatively small $(n=30)$, with individuals falling into two broad groups

403 based on $\delta^{15} \mathrm{~N}$ values. It is unknown whether the patterns in inter-individual variability in anchovy

$404 \delta^{15} \mathrm{~N}$ values we have shown are typical of the species, or even the genus. However, in their Fig. 5.

405 Espinoza et al. (2017) show both a similar range of $\delta^{15} \mathrm{~N}$ values (12 - $20 \%$.), as well as possible

406 evidence for different $\delta^{15} \mathrm{~N}$ groups from anchovies from latitudes ca. $300-350 \mathrm{~km}$ north of where

407 our samples were collected. It is possible that further intensive sampling may reveal that anchovy

408 feed along a $\delta^{15} \mathrm{~N}$ continuum rather than in discrete groups as we suggest. It is likely that this is

409 worthy of further study in other populations and Engraulis species.

410

411 An alternative explanation for the existence of two groups of anchovy differing in $\delta^{15} \mathrm{~N}$ (which we

412 associate with differences in TP) is that the sample included fish from different geographical

413 locations, where baseline $\delta^{15} \mathrm{~N}$ differed, but that had actually fed at similar TPs. Baseline $\delta^{15} \mathrm{~N}$

414 varies considerably along the Pacific coast of Chile and Peru, reflecting differences in the intensity

415 of upwelling and the associated denitrification process. De Pol-Holz and colleagues (2009)

416 reported a marked S-N gradient of ${ }^{15} \mathrm{~N}$ enrichment in marine sediments along the Chilean coast.

417 We have shown elsewhere (Docmac et al, 2017) that consumer $\delta^{15} \mathrm{~N}$ increases along a South-North

418 gradient in the study region, and that $\delta^{13} \mathrm{C}$ co-varies spatially across the same scale. Given that the

419 two putative groups of anchovy had similar $\delta^{13} \mathrm{C}$ values, we feel it is unlikely that they had different

420 origins, and that we are confident in our identification of the two groups feeding at different trophic

421 positions.

422

423 There was no evidence for any relationships between individual body mass and $\delta^{13} \mathrm{C}$ or $\delta^{15} \mathrm{~N}$ in

424 anchovy, as seen in the northern HCS by Espinoza et al. (2017), who examined fish from a larger 
425 size range. In our study, jack mackerel $\delta^{13} \mathrm{C}$ was similar across the size gradient, but showed a 426 significant but small $\left(0.6 \%\right.$ ) positive shift in $\delta^{15} \mathrm{~N}$ from the smallest (43.2 g) to the largest $(79.8 \mathrm{~g})$ 427 individual examined. In contrast to our results, Espinoza et al. (2017), again in a wider size range, 428 showed that jack mackerel $\delta^{15} \mathrm{~N}$ was negatively related with individual size in the northern HCS. 429 In order to have a reliable picture of ontogenetic shifts in $\delta^{13} \mathrm{C}$ and $\delta^{15} \mathrm{~N}$ in $\mathrm{N}$ Chile, it is clear that 430 larger samples are required both in terms of the number and of the size of individual fish.

431

432 Our estimates of anchovy consumption patterns and TP using stable isotope ratios are based on 433 several key assumptions. For example, they are reliant on the use of representative values for the 434 different prey groups and the isotopic baseline (phytoplankton) used to estimate TP, as well as for 435 trophic discrimination (isotopic differences between prey and the consumer). With regard to our 436 estimates of putative prey and the isotopic baseline, we followed a standardised sampling protocol 437 across a considerable area $\left(>2000 \mathrm{~km}^{2}\right)$, which is likely representative for the wider region. Such 438 wide-scale sampling should be sufficient to account for spatial differences in phytoplankton and 439 prey $\delta^{15} \mathrm{~N}$ associated with variation in in upwelling intensity, and hence the relative enrichment in $440{ }^{15} \mathrm{~N}$ associated with this process (Reddin et al. 2015)).

442 However, upwelling intensity (and the relative amount of ${ }^{15} \mathrm{~N}$-enrichment) in the region also varies 443 on a temporal scale (Herrera \& Escribano 2006), raising the possibility of a disconnect between 444 phytoplankton (which rapidly reflect isotopic changes) and anchovies, whose tissue $\delta^{15} \mathrm{~N}$ values 445 may reflect conditions in an earlier time period, e.g. when phytoplankton $\delta^{15} \mathrm{~N}$ was different than 446 during the study period. Such isotopic decoupling has been reported elsewhere (O'Reilly \& Hecky 447 2002) and, if not identified, can potentially confuse estimates of fish TP. We do not think this is a 
448 major issue in our study as the presence of favourable winds year-round means than coastal 449 upwelling occurs throughout the year in the study region (Palma et al. 2006; Thiel et al. 2007). 450 This suggest that there is unlikely to be a marked seasonal shift in $\delta^{15} \mathrm{~N}$ values at the base of the 451 food web that could lead to us underestimating baseline $\delta^{15} \mathrm{~N}$. Furthermore, anchovy growth is 452 rapid in the study region, and continues throughout the year (Cerna \& Plaza 2016), lowering the 453 risk of seasonal decoupling from a dynamic isotopic baseline.

454

455 In terms of TDF, we used a commonly applied $\Delta^{15} \mathrm{~N}$ TDF of $3.4 \pm 1.0 \%$ to allow direct 456 comparisons with Espinoza et al. (2017). This value represents a mean estimated from many 457 different habitats, feeding strategies and taxa (Post 2002). Studies of carnivorous fish often use a 458 smaller $\Delta^{15} \mathrm{~N}$ value of $2.9 \pm 0.3 \%$, following McCutchan et al. (2003). Use of these values would 459 increase our estimates of anchovy TP. Beyond the actual mean values used, it is also important to 460 note that our estimates of TP were calculated following a robust Bayesian approach that includes 461 error in both in diet-tissue TDF and baseline $\delta^{15} \mathrm{~N}$ (Quezada-Romegialli et al. 2018). Our approach 462 however relies on the assumption that TDFs are additive, and this has been criticised by some 463 authors. Caut et al. (2009) suggested that TDFs decrease with greater concentrations of ${ }^{15} \mathrm{~N}$ in the 464 diet, and Hussey et al. (2014) developed a model to estimate what they refer to as scaled-TP. Their 465 model includes a threshold (named $\delta^{15} N_{l i m}$ ) estimating the situation where $\delta^{15} \mathrm{~N}$ in the diet is such 466 that trophic discrimination is expected to be zero. $\delta^{15} N_{\text {lim }}$ is calculated based on estimates for the 467 slope $\left(\beta_{0}\right)$ and the intercept $\left(\beta_{1}\right)$ of a negative relationship between consumer TDF and the $\delta^{15} \mathrm{~N}$ of 468 their food based on experimental feeding studies. Using the Bayesian median estimates provided 469 by Hussey and colleagues based on a meta-analysis, $\delta^{15} N_{\text {lim }}$ has a value of $21.9 \%$. Many 470 consumers in the HCS of N Chile including benthic rockfish (Docmac et al. 2017) and the pelagic 
471 fishes detailed here (jack mackerel and high $\delta^{15} \mathrm{~N}$ anchovies) have $\delta^{15} \mathrm{~N}$ values greater than this

472 threshold. This not only prevents the calculation of scaled TP estimates in these naturally ${ }^{15} \mathrm{~N}-$

473 enriched consumers, but highlights that the relationship between experimentally-derived TDF and

474 dietary $\delta^{15} \mathrm{~N}$ at the heart of the scaled-TP approach does not extend to natural ecosystems where

$475 \delta^{15} \mathrm{~N}$ is naturally high. Although this does not discount the Hussey et al. method, it does highlight

476 that it is not universally applicable, and raises the need for more experimental studies.

477

478 Our mixing model results reflect an attempt to estimate the relative contribution of seven different

479 putative prey groups using only two different isotopes. Although Bayesian mixing models can

480 provide useful results where the number of potential sources is greater than the number of markers

481 used (Phillips et al. 2014), the performance of our model might have been limited by both the large

482 number of prey groups and the fact that some of our prey groups were isotopically similar (See

483 Fig. 2), even though these groups differed taxonomically (and functionally). We attempted to 484 counter this by including information on prey elemental concentration in the model (i.e. we used 485 a concentration-dependent model) which will likely be most useful in distinguishing between 486 animal and phytoplankton prey (Phillips et al. 2014). Given these caveats, we feel confident that 487 our mixing model results (Fig. 4), support our conclusions that 1. anchovy are not assimilating 488 significant amounts of $\mathrm{C}$ and $\mathrm{N}$ from phytoplankton; 2. that the anchovy population includes 489 individuals feeding on two broad groups of animal prey, i.e. consumption of crustacean larvae by 490 the low $\delta^{15} \mathrm{~N}$ anchovy group, and ichthyoplankton (eggs and preflexion-stage anchovy larvae) by 491 the high $\delta^{15} \mathrm{~N}$ anchovy group (as well as juvenile jack mackerel). 
493 Our data indicate that anchovy diet is both more variable than is generally considered and that 494 some individuals can feed at high trophic positions. It has become increasing clear that populations 495 of consumers can include individuals following specialised trophic strategies (Bolnick et al. 2003).

496 The inclusion of different trophic specialisms within anchovy populations may contribute to their 497 productivity by limiting intraspecific competition and support the unusually high fish production 498 associated with the HCS (Bakun \& Weeks 2008; Chavez \& Messié 2009). The cannibalism and 499 predation of eggs and larvae we suggest for the high $\delta^{15} \mathrm{~N}$ anchovy group is commonly reported in 500 clupeiform fishes (Alheit 1987; Hunter 1981), allowing consumption of an energy-rich prey 501 (Konchina 1991). The study area is recognised as a spawning and nursery area for fish, particularly 502 anchovies (Palma et al. 2006; 1992). Given that anchovies and other fishes can spawn throughout 503 the year in the region, this potentially results in a permanent supply of early life stage prey to 504 predators, but may represent an important driver of natural mortality, with potential implications 505 for future recruitment success.

506

507

508

509 Conclusions

510 We used a stable isotope approach to examine the trophic ecology of one of the world's most 511 important (but apparently understudied) fishes in an extremely productive, coastal upwelling zone.

512 Our work has revealed several important findings with implications for how we understand and 513 manage this important resource. We have shown that, like previous studies using stable isotopes 514 from both central Chile (Hückstadt et al. 2007) and Peru (Espinoza et al. 2017), that anchovy TP 515 has likely been considerably underestimated. Our estimates of anchovy TP differ from the classic 516 value (2.2) used in much of the fisheries literature (Guénette et al. 2008; Pauly et al. 1998), and 517 support Espinoza et al.'s (2017) observation that the classical hypothesis that short and efficient 
518 food chains drive secondary production in this ecosystems (Ryther 1969) is no longer valid. We

519 also have shown that the trophic ecology of individual anchovies is far more complicated than

520 previously considered - individuals captured in the same net, fell into two broad trophic groups,

521 even though they were largely of a similar size. These groups differed in trophic position and

522 estimated diet, revealing previously unrecognised trophic variation in a fish that has long been

523 considered to indiscriminately consume phytoplankton (i.e. TP 2.2). Given the similarities with

524 the data presented by Espinoza et al. (2017) from anchovies further north in their distribution

525 (which also showed considerable variation in $\delta^{15} \mathrm{~N}$ ), it is clear that any model assuming that

526 anchovy are feeding at a low TP is suspect, and management decisions based on such models

527 should be reconsidered.

528

529

530 Our use of stable isotope analysis to characterise ecosystem function in the pelagic zone of the

531 HCS has shown that the system is more complex than previously thought. This parallels a recent

532 study where, using a similar approach, we challenged long-held assumptions regarding energy

533 supply in coastal kelp forest ecosystems in the north of Chile (Docmac et al. 2017). The current

534 study highlights the utility of stable isotope analysis as a means to reveal cryptic ecological

535 variation in systems that are generally considered well described. We are currently examining

536 amino acid $\delta^{15} \mathrm{~N}$ of different pelagic fishes from northern Chile including anchovy and jack

537 mackerel to examine whether we see similar estimates of TP (McClelland \& Montoya 2002) and

538 levels of individual variation as seen here with isotope analysis of bulk materials.

539

540 Acknowledgements 
541 We thank the handling editor and three different reviewers for useful comments on an earlier

542 version of the manuscript.

543

544

545

546

\section{References}

548 Alegre A, Bertrand A, Espino M, Espinoza P, Dioses T, Ñiquen M, Navarro I, Simier M, and

549

550

551

552

553

554

555

556

557

558

559

560

561

562

563

564

565

566

567

568

569

570 Ménard F. 2015. Diet diversity of jack and chub mackerels and ecosystem changes in the northern Humboldt Current system: A long-term study. Progress In Oceanography 137:299-313. https://doi.org/10.1016/j.pocean.2015.07.010

Alheit J. 1987. Egg cannibalism versus egg predation: their significance in anchovies. South African Journal of Marine Science 5:467-470.

Anderson MJ, Gorley RN, and Clarke KR. 2008. PERMANOVA+for PRIMER: Guide to Software and Statistical Methods. Plymouth, UK: PRIMER-R.

Bakun A. 1996. Patterns in the ocean: ocean processes and marine population dynamics. San Diego, CA, USA and La Paz, Mexico: California Sea Grant, in cooperation with Centro de Investigaciones Biologicas del Noroeste.

Bakun A, and Weeks SJ. 2008. The marine ecosystem off Peru: What are the secrets of its fishery productivity and what might its future hold? Progress In Oceanography 79:290299. https://doi.org/10.1016/j.pocean.2008.10.027

Ballón M, Bertrand A, Lebourges-Dhaussy A, Gutiérrez M, Ayón P, Grados D, and Gerlotto F. 2011. Is there enough zooplankton to feed forage fish populations off Peru? An acoustic (positive) answer. Progress In Oceanography 91:360-381.

https://doi.org/10.1016/j.pocean.2011.03.001

Bligh EG, and Dyer WJ. 1959. A rapid method of total lipid extraction and purification. Canadian Journal of Biochemistry and Physiology 37:911-917.

Bolnick DI, Svanbäck R, Fordyce JA, Yang LH, Davis JM, Hulsey CD, and Forister ML. 2003. The ecology of individuals: Incidence and implications of individual specialization. American Naturalist 161:1-28. https://doi.org/10.1086/343878 
571 Bolnick DI, Yang LH, Fordyce JA, Davis JM, and Svanbäck R. 2002. Measuring individual572 level resource specialization. Ecology 83:2936-2941. https://doi.org/10.1890/0012573 9658(2002)083[2936:MILRS]2.0.CO;2

574 Carabel S, Godinez-Dominguez E, Verisimo P, Fernandez L, and Freire J. 2006. An assessment

575 576 577 578 579 580 581 582 583 584 585 586 587 588 589 590 591 592 593 594 595 596 597 598 599 600 601 of sample processing methods for stable isotope analyses of marine food webs. Journal of Experimental Marine Biology and Ecology 336:254-261. https://doi.org/10.1016/j.jembe.2006.06.001

Casciotti KL. 2016. Nitrogen and oxygen isotopic studies of the marine nitrogen cycle. Annual Review of Marine Science 8:379-407. doi:10.1146/annurev-marine-010213-135052

Castillo J, Córdova J, Saavedra A, Espejo M, Gálvez P, Barbieri MA, Osses J, Reyes H, Arriagada G, Barría P, Gili R, Oliva E, and Brieba C. 2002. Evaluación del reclutamiento de anchoveta en la I y II Regiones, temporada 2001-2002. Informe Final Proyecto FIP No2001-11: http://www.subpesca.cl/fipa/613/articles-88966_informe_final.pdf. Valparaíso, Chile: Instituto de Fomento Pesquero, Chile.

Castillo J, Saavedra A, Leiva F, Reyes H, Pizarro M, Espíndola F, Castati V, Lang C, Hernández CE, Leiva B, Cerna F, López A, Herrera L, Claramunt G, Oliva E, Moreno P, and Medina M. 2011. Evaluación hidroacústica del reclutamiento de la anchoveta en la XV, I y II Regiones, año 2010. Informe Final Proyecto FIP No 2009-02. http://www.subpesca.cl/fipa/613/articles-89269_informe_final.pdf Valparaíso, Chile: Instituto de Fomento Pesquero, Chile.

Caut S, Angulo E, and Courchamp F. 2009. Variation in discrimination factors $\left(\delta^{15} \mathrm{~N}\right.$ and $\left.\delta^{13} \mathrm{C}\right)$ : the effect of diet isotopic values and applications for diet reconstruction. Journal of Applied Ecology 46:443-453. https://doi.org/10.1111/j.1365-2664.2009.01620.x

Cerna F, and Plaza G. 2016. Daily growth patterns of juveniles and adults of the Peruvian anchovy (Engraulis ringens) in northern Chile. Marine And Freshwater Research 67:899-912. https://doi.org/10.1071/MF15032

Chavez FP, Bertrand A, Guevara-Carrasco R, Soler P, and Csirke J. 2008. The northern Humboldt Current System: Brief history, present status and a view towards the future. Progress In Oceanography 79:95-105. http://dx.doi.org/10.1016/j.pocean.2008.10.012 Chavez FP, and Messié M. 2009. A comparison of eastern boundary upwelling ecosystems. Progress In Oceanography 83:80-96. http://dx.doi.org/10.1016/j.pocean.2009.07.032 
602 Clarke KR, and Gorley RN. 2015. PRIMER v7: User Manual/Tutorial. Plymouth: PRIMER-E.

603 Cury P. 2000. Small pelagics in upwelling systems: patterns of interaction and structural changes

604 in "wasp-waist" ecosystems. ICES Journal of Marine Science 57:603-618.

605 https://doi.org/10.1006/jmsc.2000.0712

606

607

608

609

610

611

612

613

614

615

616

617

618

619

620

621

622

623

624

625

626

627

628

629

630

631

De Pol-Holz R, Robinson RS, Hebbeln D, Sigman DM, and Ulloa O. 2009. Controls on sedimentary nitrogen isotopes along the Chile margin. Deep Sea Research Part II: Topical Studies in Oceanography 56:1042-1054. http://dx.doi.org/10.1016/j.dsr2.2008.09.014

Docmac F, Araya M, Hinojosa IA, Dorador C, and Harrod C. 2017. Habitat coupling writ large: pelagic-derived materials fuel benthivorous macroalgal reef fishes in an upwelling zone. Ecology 98:2267-2272. 10.1002/ecy.1936

Espinoza P, and Bertrand A. 2008. Revisiting Peruvian anchovy (Engraulis ringens) trophodynamics provides a new vision of the Humboldt Current system. Progress In Oceanography 79:215-227. http://dx.doi.org/10.1016/j.pocean.2008.10.022

Espinoza P, Lorrain A, Ménard F, Cherel Y, Tremblay-Boyer L, Argüelles J, Tafur R, Bertrand S, Tremblay Y, Ayón P, Munaron J-M, Richard P, and Bertrand A. 2017. Trophic structure in the northern Humboldt Current system: new perspectives from stable isotope analysis. Marine Biology 164:86. 10.1007/s00227-017-3119-8

FAO. 2018. Fisheries and aquaculture software. FishStatJ - software for fishery statistical time series. Rome: FAO Fisheries and Aquaculture Department.

Fry B, and Wainright SC. 1991. Diatom sources of ${ }^{13} \mathrm{C}$-rich carbon in marine food webs. Marine Ecology-Progress Series 76:149-157.

Fuenzalida R, Escribano R, Oliva ME, Garcés J, Rosales S, Claramunt G, Morales C, Herrera L, Santander E, Rojo M, Pizarro P, Carrasco C, Moreno P, and Azocar C. 2009. Efectos de la variabilidad de la capa mínimo de oxígeno (CMO) en la distribución y la abundancia de los principales recursos pesqueros de la zona norte. Informe Final Proyecto FIP $N^{o}$ 2007-45 http://www.subpesca.cl/fipa/613/articles-89212_informe_final.pdf. Iquique, Chile: Depto. Ciencias del Mar, Universidad Arturo Prat.

Giesecke R, and González HE. 2004. Mandible characteristics and allometric relations in copepods: a reliable method to estimate prey size and composition from mandible 
632

633

634 Guénette S, Christensen V, and Pauly D. 2008. Trophic modelling of the Peruvian upwelling 635 636 637 638 639 640 641 642 643 644 645 646 647 648 occurrence in predator guts. Revista Chilena De Historia Natural 77:607-616. http://dx.doi.org/10.4067/S0716-078X2004000400004 79:326-335. https://doi.org/10.1016/j.pocean.2008.10.005

Harrod C, Grey J, McCarthy TK, and Morrissey M. 2005. Stable isotope analyses provide new insights into ecological plasticity in a mixohaline population of European eel. Oecologia 144:673-683. DOI 10.1007/s00442-005-0161-X

Herrera L, and Escribano R. 2006. Factors structuring the phytoplankton community in the upwelling site off El Loa River in northern Chile. Journal of Marine Systems 61:13-38. https://doi.org/10.1016/j.jmarsys.2005.11.010

Hückstadt LA, Rojas CP, and Antezana T. 2007. Stable isotope analysis reveals pelagic foraging by the Southern sea lion in central Chile. Journal of Experimental Marine Biology and Ecology 347:123-133. https://doi.org/10.1016/j.jembe.2007.03.014

Hunter JR. 1981. Feeding ecology and predation of marine fish larvae. In: Lasker R, ed. Marine Fish Larvae: Morphology, Ecology and Relations to Fisheries. Seattle, USA: University of Washington Press.

Hussey NE, MacNeil MA, McMeans BC, Olin JA, Dudley SFJ, Cliff G, Wintner SP, Fennessy ST, and Fisk AT. 2014. Rescaling the trophic structure of marine food webs. Ecology Letters 17:239-250. 10.1111/ele.12226

Hynes HBN. 1950. The food of fresh-water sticklebacks (Gasterosteus aculeatus and Pygosteus pungitius), with a review of methods used in studies of the food of fishes. Journal of Animal Ecology 19:36-58.

Hyslop EJ. 1980. Stomach contents analysis - a review of methods and their application. Journal Of Fish Biology 17:411-429. https://doi.org/10.1111/j.1095-8649.1980.tb02775.x

Kämpf J, and Chapman P. 2016. Upwelling Systems of the World: A Scientific Journey to the Most Productive Marine Ecosystems. Cham, Switzerland: Springer International Publishing.

Konchina YU. 1991. Trophic status of the Peruvian anchovy and sardine. Journal of Applied Ichthyology 31:59-72. 
662 Magozzi S, Yool A, Vander Zanden HB, Wunder MB, and Trueman CN. 2017. Using ocean

663

664

665

666

667

668

669

670

671

672

673

674

675

676

677

678

679

680

681

682

683

684

685

686

687

688

689

690 models to predict spatial and temporal variation in marine carbon isotopes. Ecosphere 8:e01763-n/a. 10.1002/ecs2.1763

McClelland JW, and Montoya JP. 2002. Trophic relationships and the nitrogen isotopic composition of amino acids in plankton. Ecology 83:2173-2180. 10.1890/00129658(2002)083[2173:TRATNI]2.0.CO;2

McCutchan JH, Lewis WM, Kendall C, and McGrath CC. 2003. Variation in trophic shift for stable isotope ratios of carbon, nitrogen, and sulfur. Oikos 102:378-390. https://doi.org/10.1034/j.1600-0706.2003.12098.x

Medina M, Herrera L, Castillo J, Jaque J, and Pizarro N. 2015. Alimentación de la anchoveta (Engraulis ringens) en el norte de Chile (18 $\left.25^{\circ}-25^{\circ} 40^{\prime} \mathrm{S}\right)$ en diciembre de 2010. Latin American Journal of Aquatic Research 43:46-58. http://dx.doi.org/10.3856/vol43-issue1fulltext-5

Nielsen JM, Clare EL, Hayden B, Brett MT, Kratina P, and Gilbert MTP. 2018. Diet tracing in ecology: Method comparison and selection. Methods in Ecology and Evolution 9:278291. doi:10.1111/2041-210X.12869

O'Reilly CM, and Hecky RE. 2002. Interpreting stable isotopes in food webs: Recognizing the role of time averaging at different trophic levels. Limnology and Oceanography 47:306309. https://doi.org/10.4319/10.2002.47.1.0306

Orrego H, and Mendo J. 2015. Hábitos alimenticios del jurel Trachurus murphyi (Nichols) en la zona nor-central del mar peruano. Ecología Aplicada 14:103-113.

Palma W, Escribano R, and Rosales S. 2006. Modeling study of seasonal and inter-annual variability of circulation in the coastal upwelling site of the El Loa River off northern Chile. Estuarine Coastal and Shelf Science 67:93-107. https://doi.org/10.1016/j.ecss.2005.11.011

Palma W, Pizarro J, and Flores C. 1992. Co-ocurrencia, distribución y abundancia de los estados tempranos de Engraulis ringens y Sardinops sagax (Pisces: Clupeiformes) en un área de surgencia costera en el norte de Chile. Investigaciones Científicas y Tecnológicas, serie: Ciencias del Mar 2:12-30. 
691 Parnell AC, Phillips DL, Bearhop S, Semmens BX, Ward EJ, Moore JW, Jackson AL, Grey J, 692 Kelly DJ, and Inger R. 2013. Bayesian stable isotope mixing models. Environmetrics 693 24:387-399. 10.1002/env.2221

694 Pauly D, Christensen V, Dalsgaard J, Froese R, and Torres F, Jr. 1998. Fishing down marine 695 food webs. Science 279:860-863. DOI: 10.1126/science.279.5352.860

696

Pauly D, Froese R, and Palomares ML. 2000. Fishing Down Aquatic Food Webs. American

697 Scientist 88:46-51. DOI: 10.1511/2000.1.46

698

Phillips DL, Inger R, Bearhop S, Jackson AL, Moore JW, Parnell AC, Semmens BX, and Ward 699 EJ. 2014. Best practices for use of stable isotope mixing models in food web studies.

700 Canadian Journal Of Zoology 92:823-835. 10.1139/cjz-2014-0127

701

702

Post DM. 2002. Using stable isotopes to estimate trophic position: models, methods, and assumptions. Ecology 83:703-718. https://doi.org/10.1890/0012-

703 9658(2002)083[0703:USITET]2.0.CO;2

704

Quezada-Romegialli C, Jackson AL, Hayden B, Kahilainen KK, Lopes C, and Harrod C. 2018. 705 tRophicPosition, an R package for the Bayesian estimation of trophic position from

706

707 consumer stable isotope ratios. Methods in Ecology and Evolution 9:1592-1599.

708 https://doi.org/10.1111/2041-210X.13009

R Core Team. 2018. R: A language and environment for statistical computing. Vienna, Austria:

709 R Foundation for Statistical Computing.

RStudio Team. 2016. RStudio: Integrated Development for R. Boston (MA), USA: RStudio Inc.

Ryther JH. 1969. Photosynthesis and fish production in the sea. Science 166:72-76.

715 10.1126/science.166.3901.72

716

Smith ADM, Brown CJ, Bulman CM, Fulton EA, Johnson P, Kaplan IC, Lozano-Montes H, 717 718 Mackinson S, Marzloff M, Shannon LJ, Shin Y-J, and Tam J. 2011. Impacts of fishing low-trophic level species on marine ecosystems. Science 333:1147-1150.

719 10.1126/science. 1209395

SYSTAT Software Inc. 2009. SYSTAT® 13.1 Richmond, CA, USA. 
721 Thiel M, Macaya EC, Acuna E, Arntz WE, Bastias H, Brokordt K, Camus PA, Castilla JC, 722 Castro LR, Cortes M, Dumont CP, Escribano R, Fernandez M, Gajardo JA, Gaymer CF, 723 Gomez I, Gonzalez AE, Gonzalez HE, Haye PA, Illanes JE, Iriarte JL, Lancellotti DA, 724 Luna-Jorquerai G, Luxoroi C, Manriquez PH, Marin V, Munoz P, Navarrete SA, Perez E,

725

726

727

728

729

730

731

732

733

734

735

736

737

738

739
Poulin E, Sellanes J, Sepulveda HH, Stotz W, Tala F, Thomas A, Vargas CA, Vasquez JA, and Vega JMA. 2007. The Humboldt Current System of northern and central Chile. In: Gibson RN, Atkinson RJA, and Gordon JDM, eds. Oceanography and Marine Biology, Vol 45. Boca Raton: Crc Press-Taylor \& Francis Group, 195-344.

Thomas SM, and Crowther TW. 2015. Predicting rates of isotopic turnover across the animal kingdom: a synthesis of existing data. Journal of Animal Ecology 84:861-870. $10.1111 / 1365-2656.12326$

Vander Zanden MJ, and Rasmussen JB. 1996. A trophic position model of pelagic food webs: impact on contaminant bioaccumulation in lake Trout. Ecological Monographs 66:451477. https://doi.org/10.2307/2963490

Whitehead PJP, Nelson GJ, and Wongratana T. 1998. FAO species catalogue Volume 7. Clupeoid fishes of the world (Suborder Clupeoidei). An annotated and illustrated catalogue of the herrings, sardines, pilchards, sprats, anchovies and wolf-herrings. Part 2. Engraulididae. FAO Fish Synopsis 125:305-579. 


\section{Table $\mathbf{1}$ (on next page)}

Summary statistics (median (credibility limits)) for estimated contribution of different putative prey 2 to the assimilated diet of anchovy (all fish combined, low $\delta^{15} \mathrm{~N}$ and high $\delta^{15} \mathrm{~N}$ groups) and jack mackerel 3 estimated using the SIMM 


\begin{tabular}{lcccc}
\hline \multicolumn{4}{c}{ Estimated proportional contribution to diet } \\
\hline Putative prey & All anchovy & $\begin{array}{c}\text { High } \delta^{15} \mathrm{~N} \\
\text { anchovy }\end{array}$ & $\begin{array}{c}\text { Low } \delta^{15} \mathrm{~N} \\
\text { anchovy }\end{array}$ & $\begin{array}{c}\text { Jack } \\
\text { mackerel }\end{array}$ \\
\hline Anchovy eggs & 0.06 & 0.08 & 0.04 & 0.15 \\
& $(0.01-0.26)$ & $(0.01-0.36)$ & $(0.01-0.15)$ & $(0.02-0.36)$ \\
\hline Anchovy larvae & 0.15 & 0.55 & 0.03 & 0.39 \\
& $(0.02-0.34)$ & $(0.11-0.74)$ & $(0.01-0.13)$ & $(0.18-0.59)$ \\
\hline Copepods & 0.03 & 0.04 & 0.03 & 0.05 \\
& $(0.01-0.1)$ & $(0.01-0.14$ & $(0.01-0.13)$ & $(0.01-0.13)$ \\
\hline Crustacean larvae & 0.61 & 0.06 & 0.73 & 0.09 \\
& $(0.37-0.77)$ & $(0.01-0.23)$ & $(0.42-0.88)$ & $(0.01-0.23)$ \\
\hline Euphausiids & 0.02 & 0.04 & 0.02 & 0.05 \\
& $(0.001-0.08)$ & $(0.01-0.15)$ & $(0.004-0.08)$ & $(0.01-0.14)$ \\
\hline Unidentified fish & 0.03 & 0.09 & 0.02 & 0.19 \\
\hline eggs & $(0.001-0.10)$ & $(0.01-0.44)$ & $(0.004-0.07)$ & $(0.05-0.34)$ \\
\hline Phytoplankton & 0.05 & 0.05 & 0.07 & 0.06 \\
\hline & $(0.001-0.22)$ & $(0.01-0.17)$ & $(0.01-0.36)$ & $(0.01-0.18)$ \\
\hline & & & & \\
\hline
\end{tabular}


Figure 1 (on next page)

Study area and position of sampling stations off the coast of $\mathrm{N}$ Chile

Dark markers represent the location where putative prey were captured, while the light grey markers show the capture location of the anchovy and jack mackerel used in the study 
Figure 2 (on next page)

Stable isotope $\delta^{15} \mathrm{~N}-\delta^{13} \mathrm{C}$ biplot showing individual values for adult anchovies (open triangles) and juvenile jack mackerel (filled triangles) captured during the current study - putative prey values are shown as mean $( \pm S D)$.

Note the considerable inter-individual differences in $\delta^{15} \mathrm{~N}$ shown by anchovies. Fish $\delta^{13} \mathrm{C}$ values reflect lipid-extracted tissues, while putative prey were not treated, as consumers assimilate carbon from different biochemical compounds in their prey including lipids. 


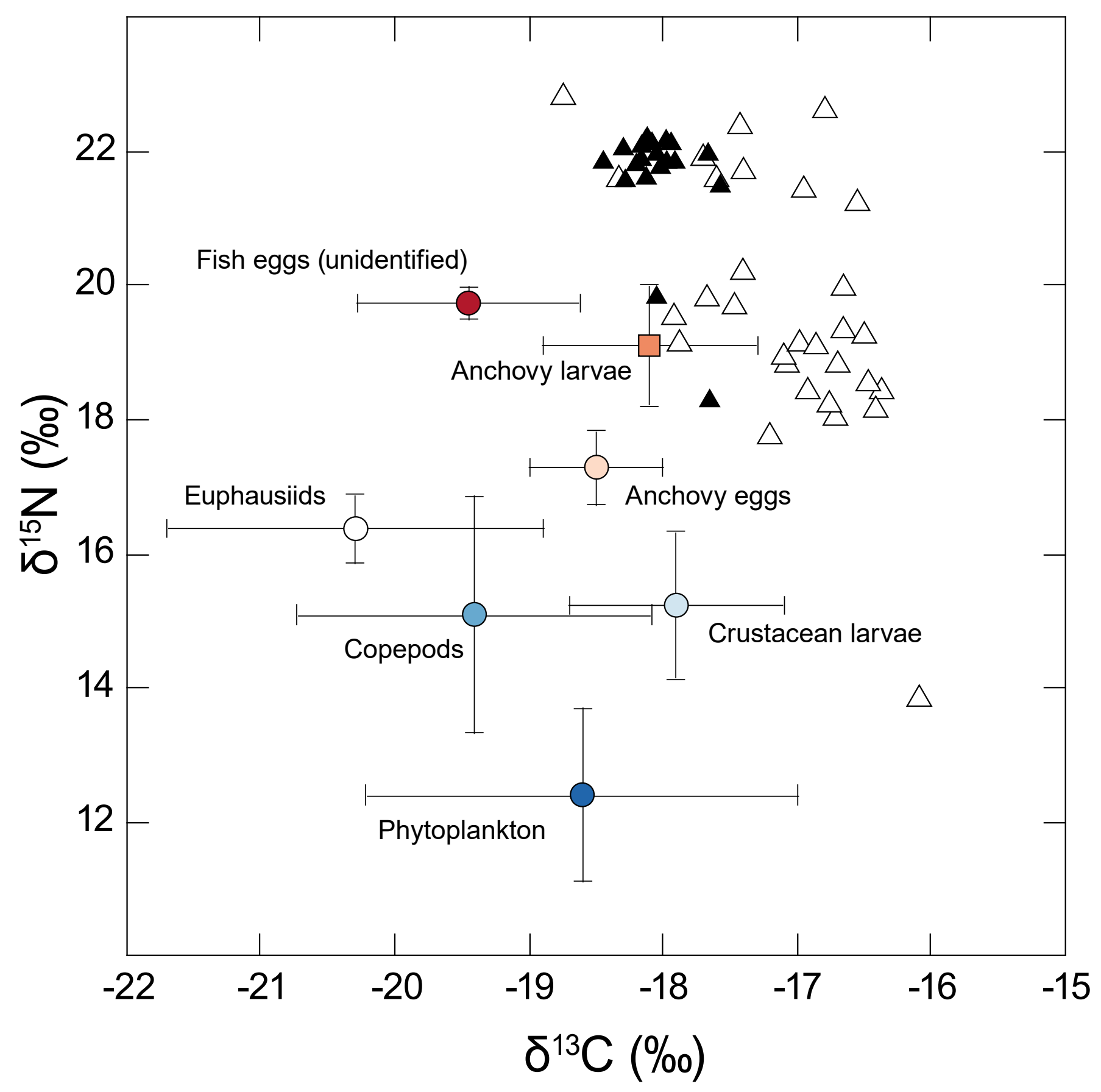


Figure 3 (on next page)

Scatterplot showing a lack of any obvious relationship between A) $\delta^{13} \mathrm{C}$ and B) $\delta^{15} \mathrm{~N}$ and fish mass in anchovy (low $\delta^{15} \mathrm{~N}=$ red triangles; high $\delta^{15} \mathrm{~N}=$ blue triangles) and juvenile jack mackerel (black triangles) 

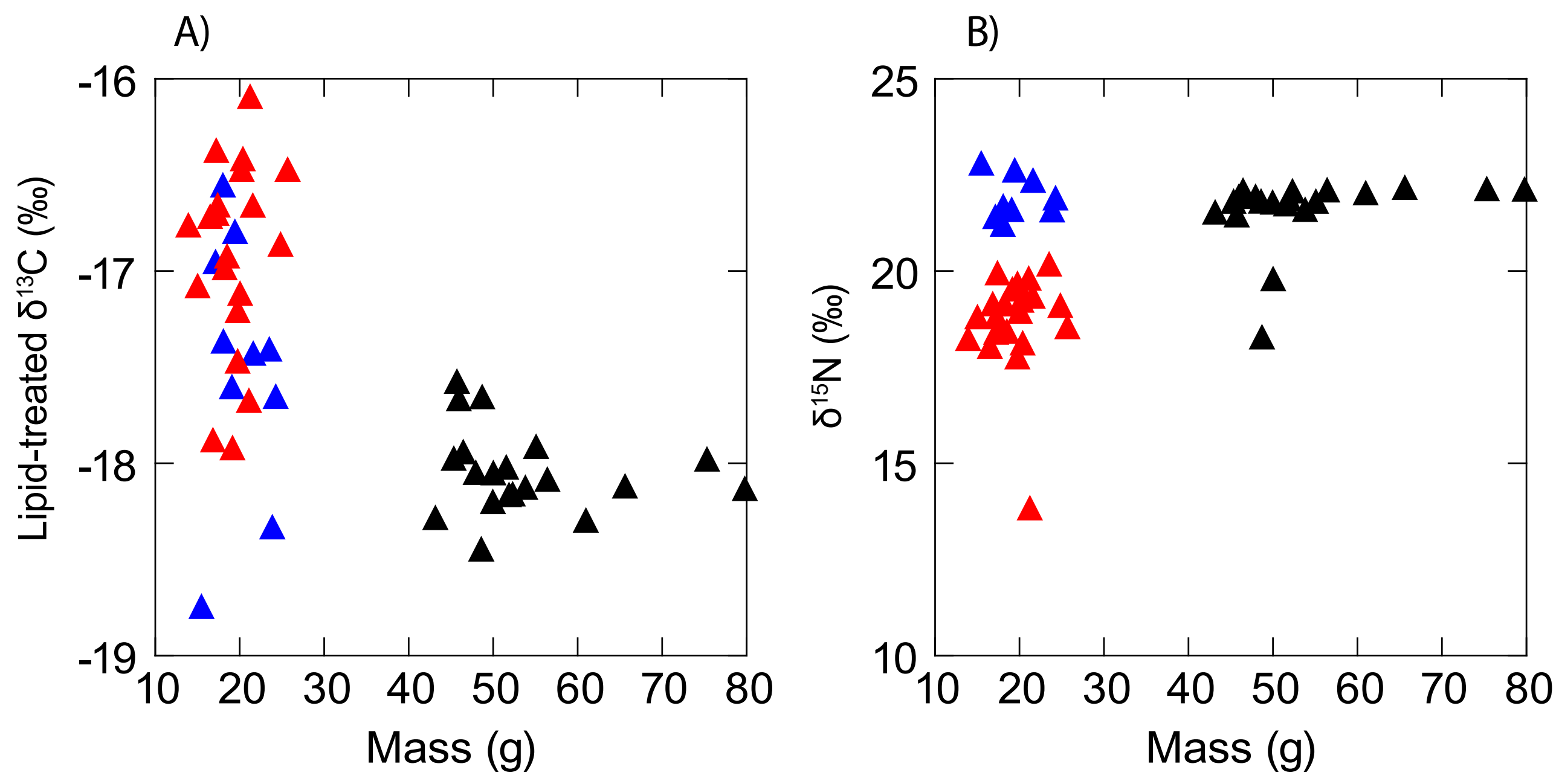
Figure 4 (on next page)

Visual representation of SIMMR mixing model results.

Boxplots showing the distribution of posterior estimates of contribution to assimilated diet of the different putative prey to: A) all anchovy, B) jack mackerel, C) low $\delta^{15} \mathrm{~N}$ anchovies, and D) B) high $\delta^{15} \mathrm{~N}$ anchovies. 
PeerJ

A) All anchovy

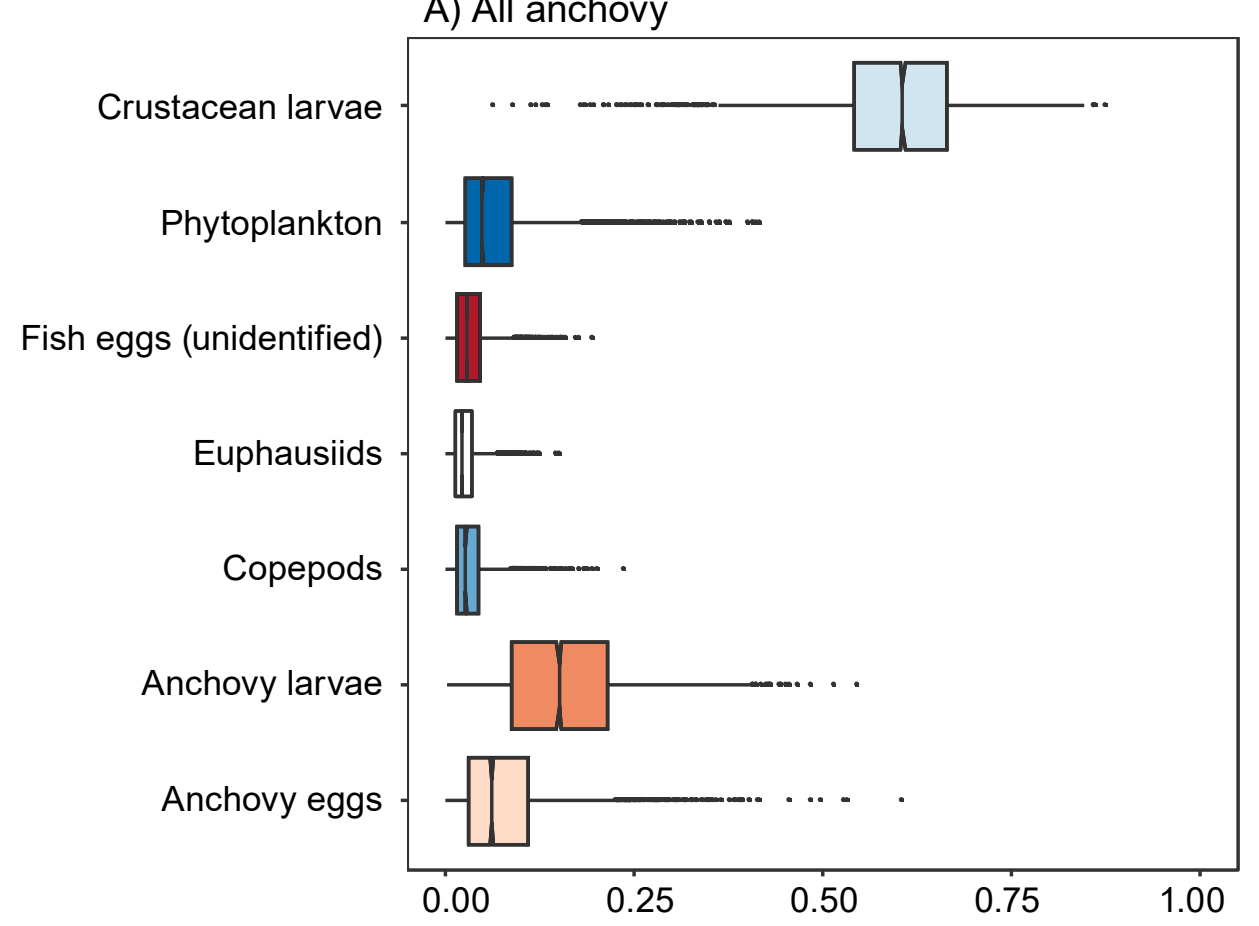

C) Low $\delta^{15} \mathrm{~N}$ anchovy

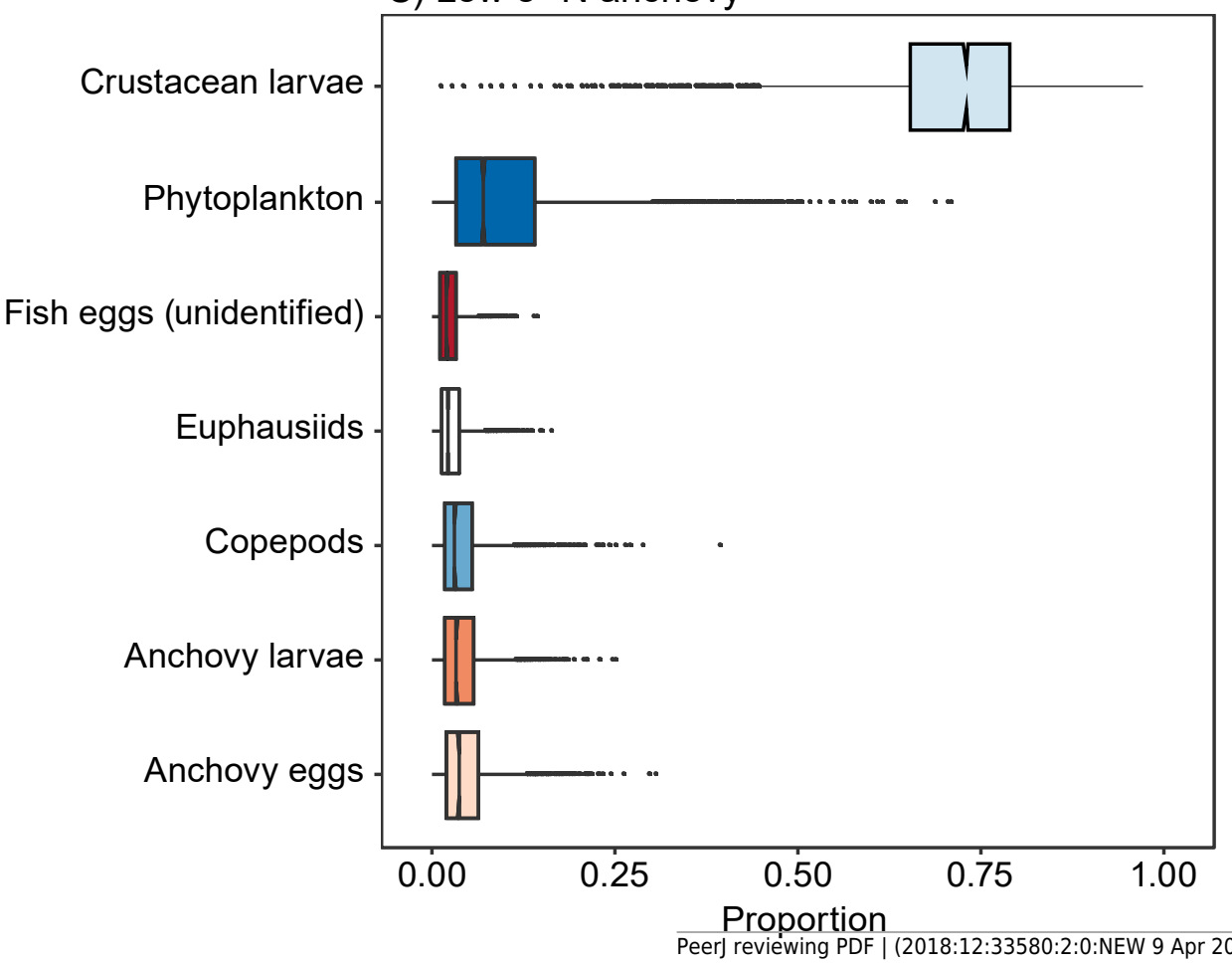

Manuscript to be reviewed

B) Jack mackerel

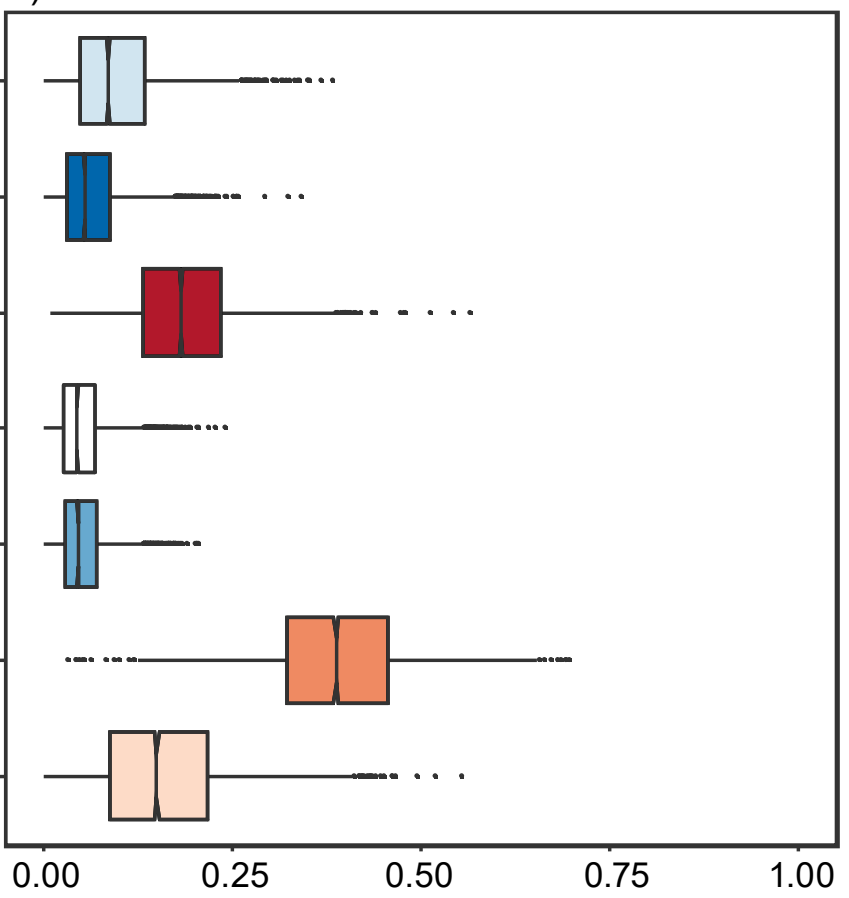

D) High $\delta^{15} \mathrm{~N}$ anchovy

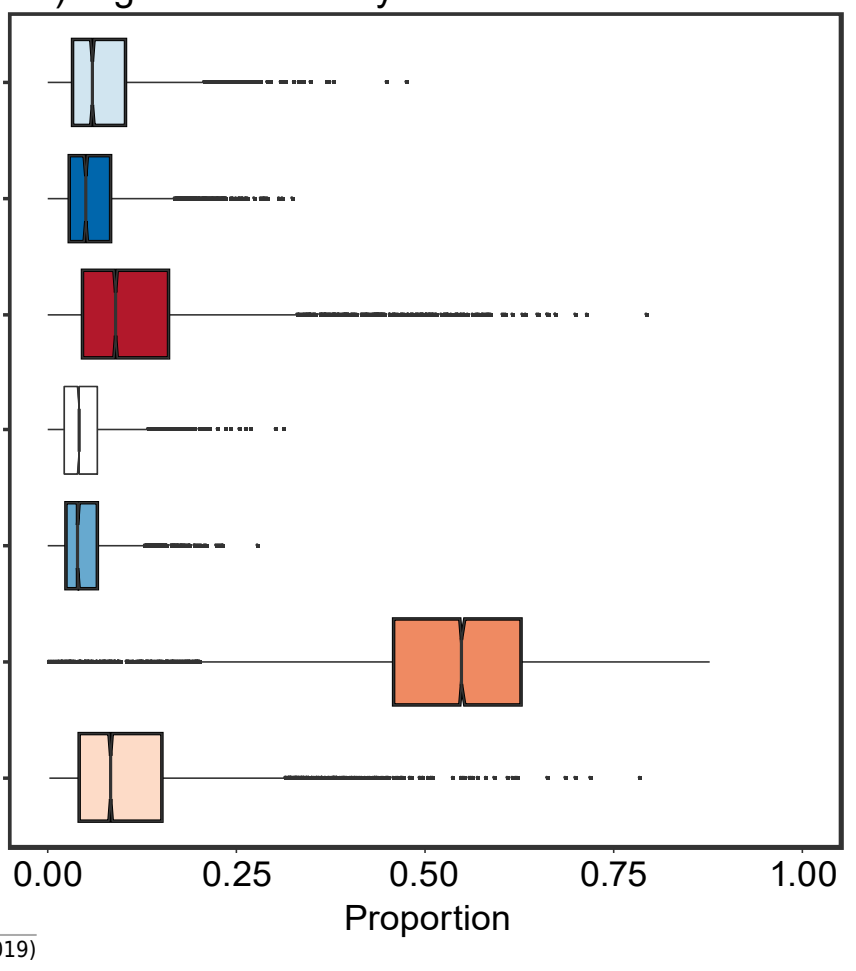


Figure $\mathbf{5}$ (on next page)

Estimates of trophic position for anchovies and jack mackerel

Bars show the modal TP (circle) $\pm 95 \%$ credibility limits, calculated relative to a phytoplankton baseline (TP1) using tRophicPosition. 


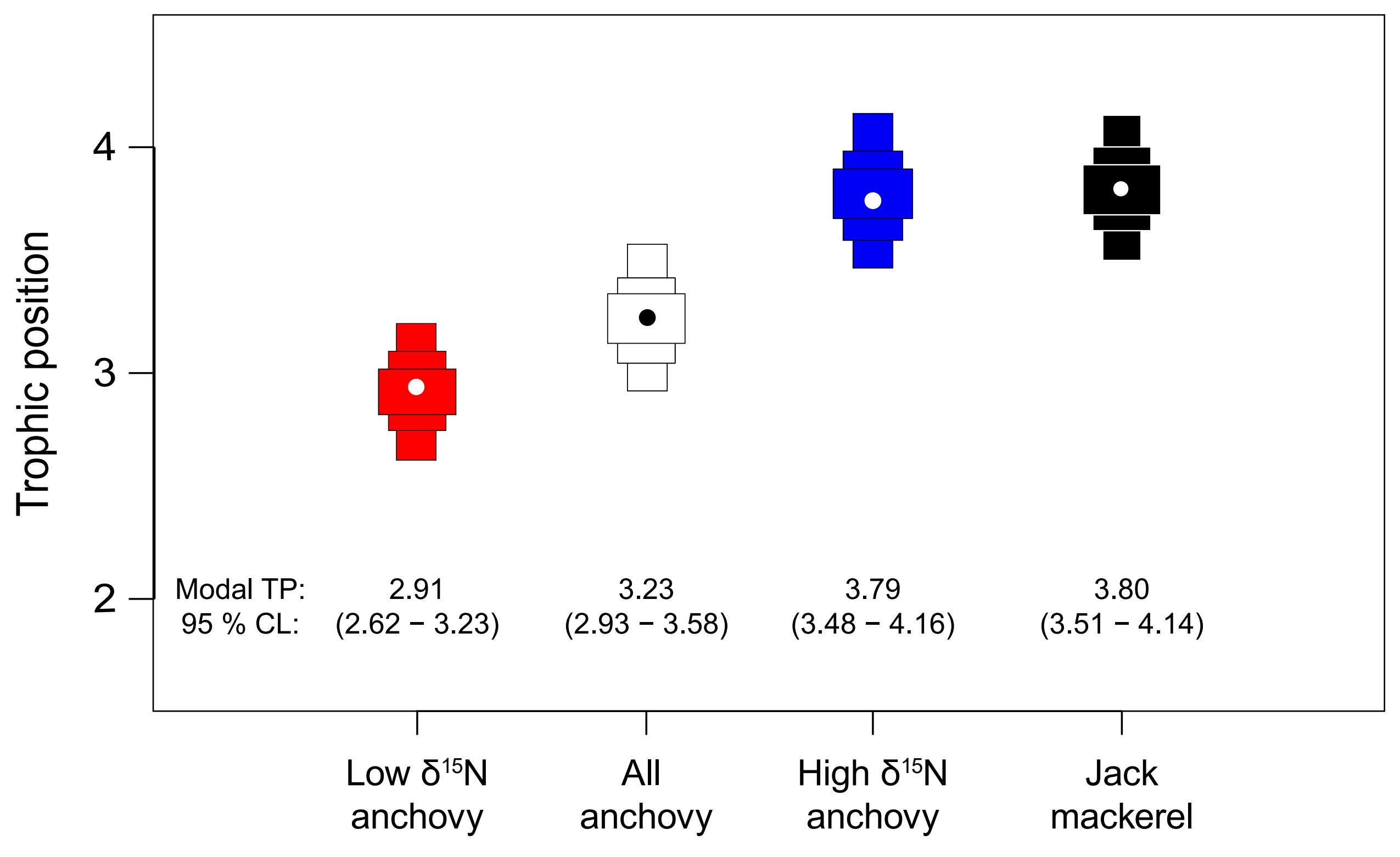

